\title{
DEVELOPMENT OF TECHNOLOGY FOR WELD REPAIR OF ANTICORROSIVE COATING OF MAIN CONNECTOR OF REACTOR WWER-440
}

\author{
S. I. Moravetsky ${ }^{1}$, O. G. Kasatkin ${ }^{1}$, A. K. Tsaryuk ${ }^{1}$, \\ V. P. Kravets ${ }^{2}$, I. V. Goncharov ${ }^{2}, A$. V. Ivanko ${ }^{2}$, \\ ${ }^{1}$ Paton Electric Welding Institute, Kyiv, Ukraine \\ ${ }^{2}$ OP "Rivne NPP", NAEC “Energoatom”, Varash, Ukraine \\ E-mail: tsaryuk@paton.kiev.ua
}

\begin{abstract}
The effect of welding method and technique on the HAZ microstructure in dissimilar welded joint of the type reactor vessel steel + deposited austenitic layer was investigated. The results of metallographic studies and bend tests of the welded joints are evidenced that the development of technology for weld repair of an anticorrosive coating with access to the base metal without subsequent high tempering is advisable on the basis of "buttered layer" technique by MMA welding with layer-by-layer controlled change in linear energy. This approach provides a uniform fine-grained microstructure at the overheat region of the HAZ. TIG welding with the filler wire and constant layer-by-layer linear energy also allows to refine overheat region microstructure. However, in this case, it is characterized by two types of structural heterogeneity caused by intense overheating of the base metal and diffusion of alloying elements and carbon.
\end{abstract}

\section{INTRODUCTION}

The main connector of nuclear reactor (MCR) is the important assembly, providing a tight connection between the reactor body and the cover. The tightness of the MCR is ensured by o-rings, which are placed in special sealing grooves on attachment flange of the reactor body and that of the cover. These grooves are performed in austenitic layer up to $9 \mathrm{~mm}$ thick deposited on each flange. These grooves are damaged during the operation of the reactor (each time the cover is removed, the o-rings are replaced with new ones). In addition, difficult operating conditions of the anticorrosive coating in the adjacency of the contact (temperature, stress, radiation and a corrosive medium), along with present defects in the welded joint, both undetected during manufacture and considered acceptable by the actual standards, lead to the growth of local damages in the austenitic layer.

Therefore, there is a need for periodical repair of the anticorrosive coating in local areas containing damages or unacceptable changes in the geometry of the sealing grooves [1]. The repair is carried out by cutting out damaged sections of the sealing surface (SS), subsequent welding up the formed cavities and, finally, machining in accordance with design dimensions.

When restoring the anticorrosive coating by arc welding, it is not allowed to melt the base metal of which the reactor vessel is made (steel 15Kh2MFA in the case WWER-440), as well as its heating to temperature $\mathrm{Ac}_{1}$ and higher [2]. This rule is observed when welding up minor cavities with a depth of not more than $60 \%$ of the thickness of the anticorrosive coating. In this case, welding materials of the same alloying are used as the deposited metal of the coating. Repair of deeper damages is associated with the heating of the base metal to the point $\mathrm{Ac}_{1}$ and higher, as well as with a danger of arc access to the base metal and its melting. In this case, heating is required before and during welding, as well as post-weld heat treatment i.e. tempering at a temperature of $650 \ldots 670{ }^{\circ} \mathrm{C}$ [2]. However, post-weld high tempering for a reactor vessel installed in a concrete well is impossible.

It is known that in a dissimilar welded joint high tempering leads to the removal of residual welding stresses only during exposure at tempering temperature. During cooling, a new stress field is formed, caused by the difference in the coefficients of thermal linear expansion of dissimilar steels fused together [3-5]. And it is not only reason for what the advisability of carrying out high tempering of welded joints low alloy steel + deposited austenitic layer, in general, seems doubtable. Nevertheless, in the case of combined welded joints in weldments of critical importance, such as the reactor vessel, it is worried about the insufficient plastic properties of HAZ metal on pearlitic steel, caused, as is known [6-8], by grain growth, melting of grain boundaries, segregation of harmful impurities and other processes that occur when the metal is held in the range from $\sim 1200{ }^{\circ} \mathrm{C}$ to the melting temperature during the thermal cycle of arc welding.

To eliminate the need for post-weld high tempering, a number of technological measures should be developed that provide a fine-grained microstructure and a sufficient level of plastic properties of HAZ metal on $15 \mathrm{Kh} 2 \mathrm{MFA}$ steel in the state after weld repair.

\section{METHODOLOGICAL PART}

As one of the effective methodological approaches, the special "buttered layer" technique proposed by authors [9-12] for repair and on-site welding of power engineering products from $\mathrm{Cr}-\mathrm{Mo}-\mathrm{V}$ steels can be considered. The use of such a welding technique eliminates the need for high tempering of the welded joint. A quite sufficient refinement of the HAZ structure and obtaining the required properties of the metal in the overheat region is ensured by repeated complete recrystallization at the temperature range from $\mathrm{Ac}_{3}$ to $1150{ }^{\circ} \mathrm{C}$ due to the controlled layer-by-layer change in the linear welding energy [13-17]. Reheating the metal 
in the overheat region to a temperature at which austenite grain not tends to growth leads to a microstructure that is similar to the fine-grained region of HAZ and contains a mixture of products of intermediate and martensite transformation.

That approach is implemented on the basis of a special technique of welding with "stringer" beads and with rational use of heat for the reheating to lastmentioned temperature range. The lower layer is made by beads with a small heat input in order to obtain the minimum dimensions of both the cross section of the beads and the associated HAZs. A certain volume of the metal of the previously deposited bead and the associated HAZ is melted by heat from the next bead. A more distant volume of the metal of the previous bead and the associated HAZ undergoes $\alpha \rightarrow \gamma \rightarrow \alpha$ transformations. The wider the second bead overlaps the first one, the greater volume of the first bead and its HAZ undergoes the transformations. If a bead is overlaped previous one up to $30 \ldots 70 \%$, optimally $50 \%$, then it results in a recrystallization and short-term high tempering in most of unmelted volume of the previous bead and the associated HAZ. This is achieved easy when the welder performs the next bead with stick electrode tilted at some angle to the side opposite from the previous one and driven along the toe of the previous bead.

When performing the lower layer, it is important to ensure the uniformity of the application of the beads: the same width, height of the beads and linear energy (welding speed). It provides to a high degree uniform microstructure of deposited beads and associated HAZs. At the same time, it states higher demands on welder's qualification and experience.

After surfacing of the 1st (lower) layer, the 2nd layer is deposited over it with the same technique. The heat introduced during surfacing of each bead of the 2nd layer is provided heat treatment of each previous bead (as in the 1st layer). A part of that heat is provided another heat treatment of lower deposited layer and its
HAZ. Another complete recrystallization of the overheat region in lower layer HAZ achieved by overlaying beads of the 2 nd layer with linear welding energy increased by $30 \ldots 70 \%$ and electrode diameter increased by $1 \mathrm{~mm}$ at once. For each electrode diameter, a welding current is assigned within the recommended values. If we assign a current from a minimum to an average for a smaller diameter, and from a medium to a maximum allowable current for a larger diameter, and do not change the welding speed, then the optimum interlayer heat input ratio is achieved.

When performing the 2nd and subsequent layers of surfacing, it is also important to ensure the uniform overlaying of the beads. Fulfillment of this requirement leads to the fact that the deposited metal practically does not contain a cast structure that has not undergone some heat treatment. Also, the HAZ on the base metal practically does not contain regions of the primarily coarse-grained structure obtained after the beads of the 1st layer were deposited. Furthermore, the volume fraction of the weld and HAZ metal subjected to shortterm high tempering exposure is increased, therefore its plastic properties in comparison with the repeatedly recrystallized metal is enhanced.

The state of development and the results of studies of the structure and properties of repair welded joints of low-alloyed steels, performed by MMA welding with "buttered layer" technique, allow, in our opinion, to recommend the above approach for developing surfacing technology to repair SS damages reached into the base metal (or thereabout) without high tempering. Going by the differences in the thermophysical properties of low- and high- alloyed austenitic steel, it was assumed that adaptation of the welding technique needs no significant changes in the above ratios, nor additional research or technical measures. So austenitic welding consumables should be selected for repair surfacing in accordance with their purpose (table). The electrodes intended for surfacing of the 2 nd layer should be taken with a diameter greater by $1 \mathrm{~mm}$.

Welding consumables for performing deposited austenitic layers on high-chromium and pearlitic steels allowed to use in ukrainian nuclear power-plant engineering [2]

\begin{tabular}{|c|c|c|c|c|}
\hline \multirow{2}{*}{$\begin{array}{c}* \\
\text { Welding }\end{array}$} & \multicolumn{3}{|c|}{ Type and purpose of surfacing } \\
\cline { 2 - 5 } & \multicolumn{2}{|c|}{ Edge pre-surfacing in welded joints } & \multicolumn{2}{c|}{ Anticorrosive coating } \\
\cline { 2 - 5 } & 1st (lower) layer & subsequent layers & 1st (lower) layer & subsequent layers \\
\hline \multirow{3}{*}{ Stick electrodes } & ЭА-395/9 & ЭА-400/10У & & ЦЛ-25/2 \\
& ЦТ-10 & ЭА-400/10Т & ЦЛ-25/1 & ЭА-898/21Б \\
& & ЦТ-26 & ЗИО-15К \\
\hline \multirow{2}{*}{ Wire or tape } & Св-10Х16Н25АМ6 & Св-04Х19Н11М3 & СВ-07Х25Н13 & Св-04Х20Н10Г2Б \\
& & & & Св-08Х19Н10Г2Б \\
\hline
\end{tabular}

\section{EXPERIMENTAL PART}

Repair welding of an anticorrosive coating with arc reached into the base metal was simulated on a test sample (Fig. 1) made of 15Kh2MFA steel with chemical composition (wt. \%): $0.16 \mathrm{C}, 0.33 \mathrm{Si}, 0.44 \mathrm{Mn}, 2.49 \mathrm{Cr}$, $0.63 \mathrm{Mo}, 0.30 \mathrm{~V}, 0.11 \mathrm{Ni}, 0.07 \mathrm{Cu}, 0.020 \mathrm{~S}, 0.019 \mathrm{P}$ Welding-up of the groove (supposed cavity after mechanical removing of a defect) was performed with the "buttered layer" technique. To assess the influence of heat input mode on character of the metal structure in the overheat region of HAZ, surfacing was performed on other samples of the same steel.

When planning experimental studies, the experience in operation and repair of dissimilar welded joints in equipment and pipelines of austenitic and pearlitic steels of WWER-440 and WWER-1000 power units [18] was taken into account. 


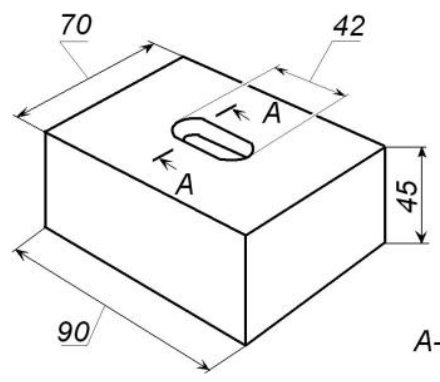

A-A

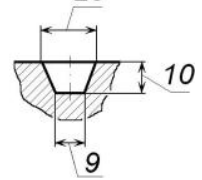

Fig. 1. Test sample to simulate repair welding with an arc access to the base metal of the reactor vessel

In those welded joints cracks and tears were identified located in the area of the first layer of preliminary surfacing of edges made by ЭA-395/9 electrodes (or wire Св-10X16H25AM6). Such defects occurred after long-term operation at the NPP units. The authors recommended to use 3ИО-8 electrodes for MMA and Св-07X25H13 filler wire for TIG even in the case of edge pre-surfacing in welded joints. So 3ИО-8 electrodes were used in experimental surfacing by MMA and $\mathrm{CB}_{\mathrm{B}}-07 \mathrm{X} 25 \mathrm{H} 13$ wire with a diameter of $2 \mathrm{~mm}$ was used for TIG.

Passes 1-6 (Fig. 2) were performed by electrodes with a diameter of $3.0 \mathrm{~mm}$ with bead overlapping about $50 \%$. The welding current was $90 \ldots 100 \mathrm{~A}$. The remaining volume of the groove (passes 7-10, some not numbered) was filled with electrodes with a diameter of $4 \mathrm{~mm}$. The welding current was $130 \ldots 140 \mathrm{~A}$.

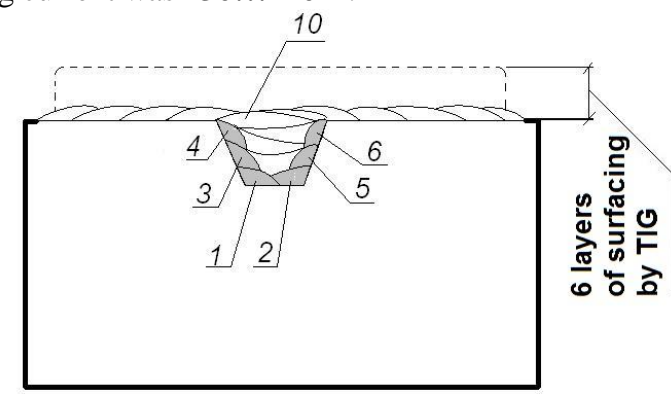

Fig. 2. Bead deposition sequence in repair groove and on the upside of test sample

After filling the groove flush with the upside, a 6-layer surfacing by the TIG method was obtained here. All passes were performed in the same mode: current $120 \mathrm{~A}$, arc voltage $10 \mathrm{~V}$. Welding speed $\left(V_{\mathrm{w}}\right)$ was given by the welder on the need of satisfactory bead forming. The total thickness of the surfacing was $5 . .6 \mathrm{~mm}$.

As a result of the ratios of depth to other linear dimensions of a local repair groove and, therefore, the insufficient convenience in handling and viewing by any manual welding method may be possible the uneven movement of the arc. In addition, the delay of the arc at the beginning and final position during each pass is practically inevitable. It is especially correct in the case of TIG. Therefore, simulating a critical case (the most unfavorable conditions for the HAZ overheating, the worst type of HAZ structure obtained without using the buttered layer technique), TIG was performed by a fixed arc with increased electric power $(I=220 \mathrm{~A} ; U=12 \mathrm{~V})$ on a $15 \mathrm{Kh} 2 \mathrm{MFA}$ steel sample (without repair groove). Guided by the same considerations, multi-pass TIG surfacing of a single layer was carried out with increased linear energy $(I=220 \mathrm{~A} ; U=12 \mathrm{~V}$; according to the results of several measurements, $V_{\mathrm{w}}$ was on average $0.0038 \mathrm{~m} / \mathrm{s}$ ). Also, to assess the character of HAZ microstructure in the overheat region by MMA welding, the "spot" surfacing $\left(V_{\mathrm{w}}=0\right)$ with the 3 ИО-8 electrode was performed. An electrode with a diameter of $3 \mathrm{~mm}$ was used at $I=130 \ldots 135 \mathrm{~A}, \quad U=20 \ldots 22 \mathrm{~V}$. The duration of the arc burning was limited by a significant degree of overheating of the electrode rod (to a glow) and amounted in this case to about $10 \mathrm{~s}$.

In all cases of the surfacing, the base metal was preheated to $160{ }^{\circ} \mathrm{C}$ and its interpass temperature was maintained no higher than $250^{\circ} \mathrm{C}$.

A metallographic study of thin sections cut out from obtained surfacings made it possible to establish the following. The surfacing of the TIG by a fixed arc led to the formation of the most unfavorable HAZ microstructure in the overheat region (Fig. 3).

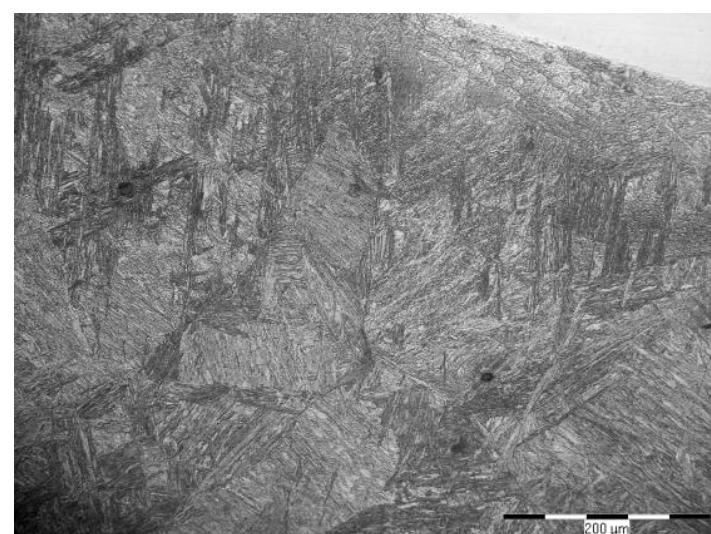

Fig. 3. The structure of the overheat region $(\times 200)$ when surfacing with TIG by a fixed arc

Long exposure of the $\gamma$-phase above the temperature of the onset of intensive grain growth $\left(\sim 1200{ }^{\circ} \mathrm{C}\right)$ caused noticeable enlargement of grains (diameter $100 \ldots 150 \mu \mathrm{m}, 3$ points according to method GOST 5639-82), increasing the homogeneity of austenite in carbon and alloying elements and, accordingly, its stability under supercooling. The structure of the coarse grain area contains upper bainite (darker areas), martensite, and some residual austenite in the grain body. In a narrow HAZ region adjacent to the fusion zone, intense diffusion of carbon into the adjacent austenitic metal proceeded. The minimum cooling rates and the achieved degree of decarburization contributed to the appearance of pearlite transformation products and granular bainite in this region (Fig. 4)

The structure of the overheat region when surfacing with stick electrod by a fixed arc is somewhat more uniform than with TIG (Fig. 5), and does not contain partially decarburized layers. The coarse grain area starts immediately from the fusion boundary (grain diameter $80 \ldots 100 \mu \mathrm{m}, 4$ points according to GOST 5639-82). 


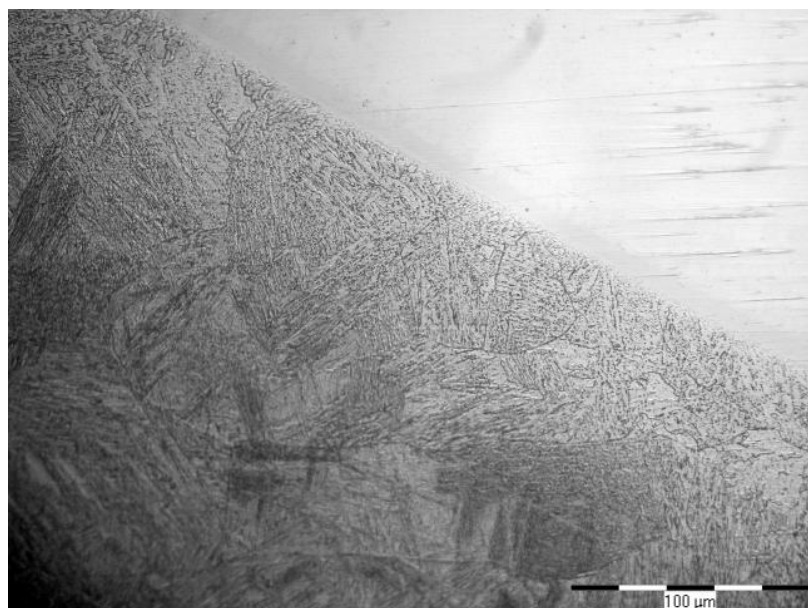

Fig. 4. HAZ structure $(\times 400)$ in the vicinity of the fusion zone when surfacing with TIG by a fixed arc

As in the case of TIG, their structure contains upper bainite, martensite and a small amount of residual austenite in the grain body. The martensitic-austenitic structure is large-block, but it is less coarse, and also the proportion of upper bainite is somewhat lower in comparison with TIG. The character of the structure of other HAZ areas of "spot" MMA surfacing does not differ significantly compared to that in the case of TIG.

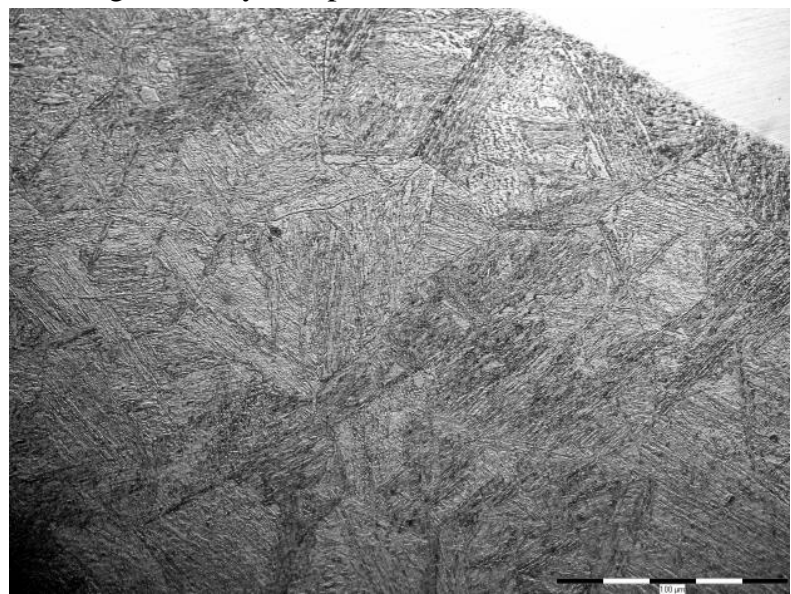

Fig. 5. The structure of the overheat region $(\times 400)$ when surfacing with MMA by a fixed arc

When a single layer is deposited with TIG on the upside of a 15Kh2MFA steel sample, there is a variety of structure types in its HAZ (Fig. 6), which is usual in the case of repeated thermal action during multi-pass welding. Short-term high tempering of the metal in overheat region of the HAZ of the previous bead due to the heat from application of the subsequent bead contributes to a decoration of the clearly marked grain boundaries by carbide particles released on them. This structure type shows up demonstratively the grain size in the overheat region of HAZ.

In contrast to the fixed arc, the surfacing of TIG beads by an arc of the same power provides a shorter holding time at temperatures above $\mathrm{Ac}_{3}$ and increased cooling rate. Therefore, the structure in the overheat area in the case of a single complete recrystallization contains increased amount of lower bainite, martensite and reduced amount of upper bainite. There is also some residual austenite. The blocks inside the grains are smaller, and the character of the structure is more uniform than when "spot" surfacing.

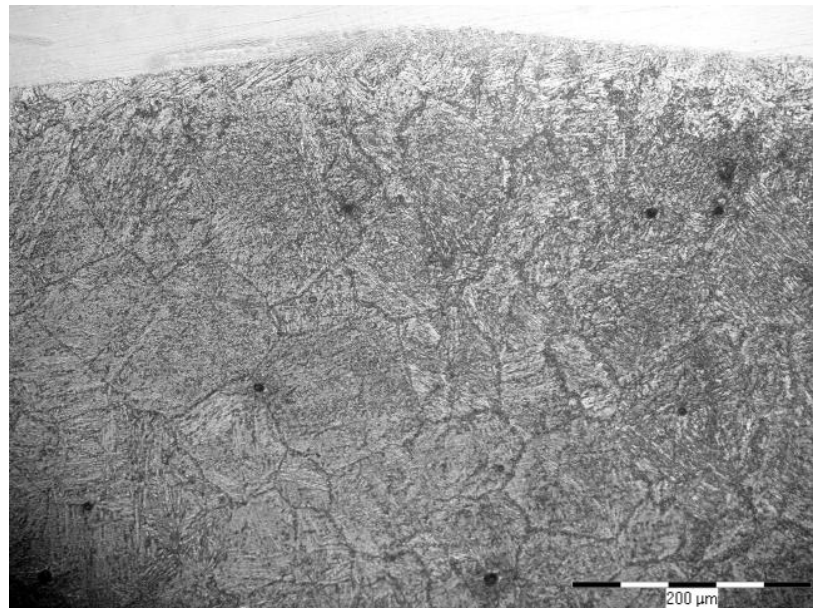

Fig. 6. The structure of the overheat region $(\times 200)$ when surfacing multi-pass TIG

Taken together, the differences revealed in the character of the structure of the HAZ metal obtained with "spot" surfacing in various ways correspond to different degrees of overheating of the base metal, which is somewhat higher in the case of TIG. It can be explained not so much by the quantity expended heat calculated by the electric parameters of the welding mode, but mainly differences in the specific features of the two welding methods (temperature, concentration and arc mobility, thickness of the liquid layer under the burning arc, heat distribution between various elements of the melting zone during welding, etc.).

In the case of a 6-layer TIG surfacing at the optimum mode, the structure character in the overheat region (Fig. 7) sharply differs from all the above described by features inherent in many times recrystallized and well tempered metal.

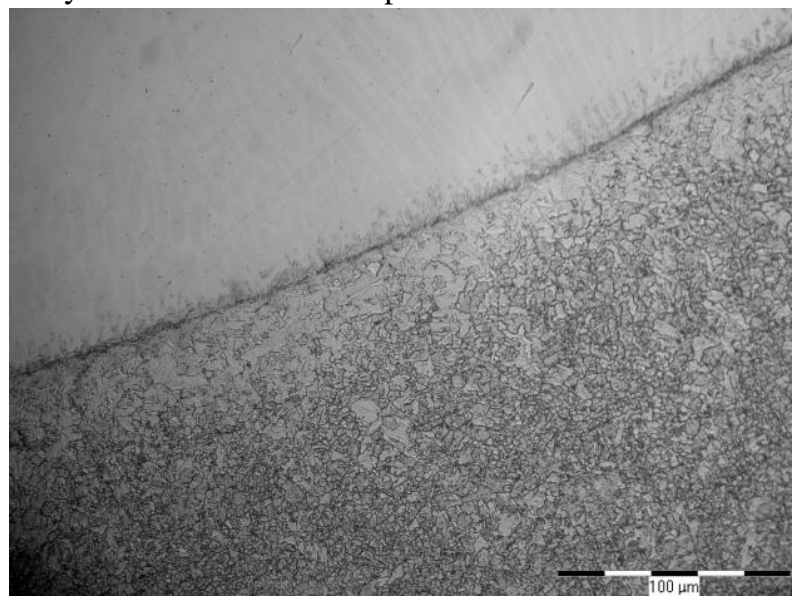

Fig. 7. The structure of the overheat region $(\times 400)$ with 6 -layer surfacing TIG in optimal mode

This achieves a very high degree of grain refinement (average grain diameter of not more than $20 \mu \mathrm{m}, 9$ points according to GOST 5639-82). The easy etched hair-line grain boundaries are observed. The grain structure varies from pure ferrite (an area adjacent to the fusion zone $\sim 0.02 \mathrm{~mm}$ wide) to a fine-grained ferritecarbide mixture (Fig. 8). This heterogeneity is caused by decarburization of the metal in this region due to the long total exposure to high temperatures, when the rate 
of diffuse movement of carbon into the austenitic deposited metal is high. Such heterogeneity may adversely affect bearing capacity of the welded joint under conditions of variable loading as a "soft" interlayer due to the reduced strength properties of the decarburized metal.

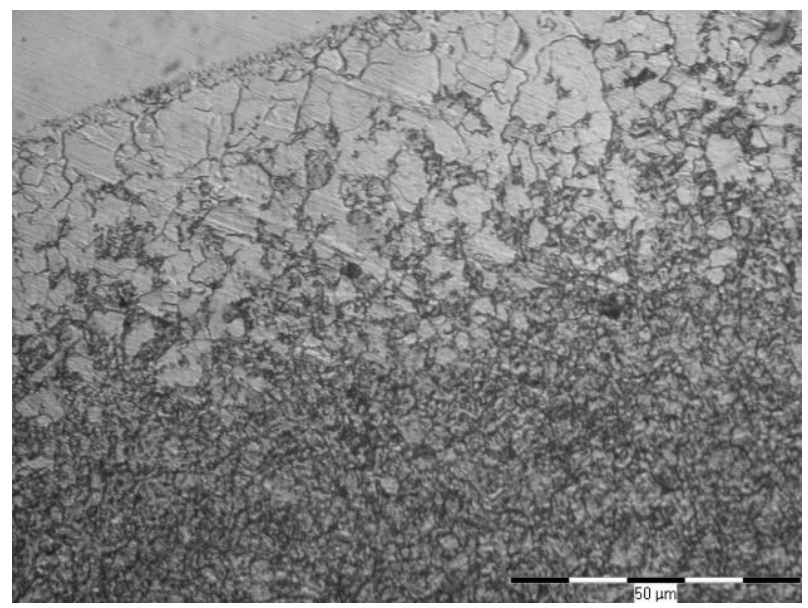

Fig. 8. The structure of the HAZ $(\times 1000)$ in the vicinity of the fusion zone with 6-layer TIG surfacing

Another type of structural heterogeneity identified in the case of 6-layer TIG surfacing is weakly etched out discontinuous interlayer $40 \ldots 60 \mu \mathrm{m}$ thick, lying between the deposited austenitic metal and the HAZ with a typical ferrite-pearlite structure. In some places, the interlayer of that structure is separated from the deposited austenitic metal by specific "island" of the base metal structure (Fig. 9), mentioned by many researchers [3, 5-7].

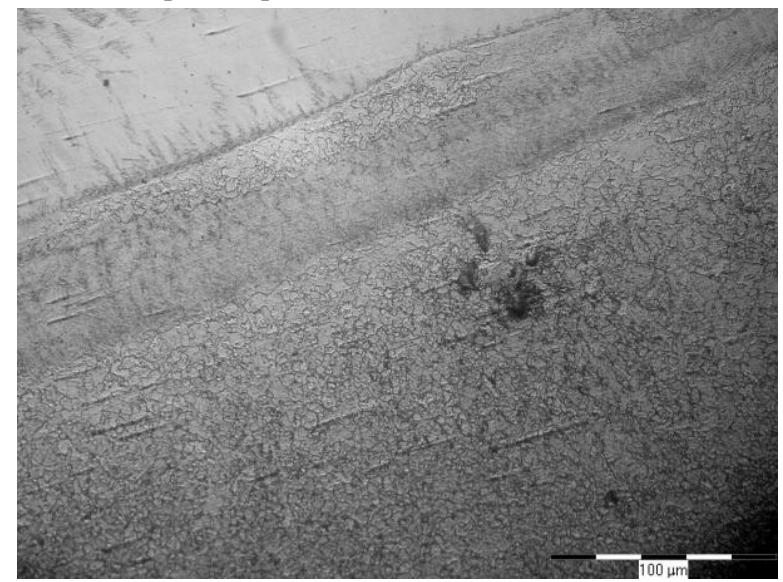

Fig. 9. Structural heterogeneity $(\times 400)$ in the vicinity of fusion zone with a 6-layer TIG surfacing

It can be assumed, this interlayer is formed by melting the border areas of the base metal, sometimes with the displacement of unmelted fragments into the weld melt without mixing with it, for example, due to the removal of heat generated during crystallization of the weld metal or irregularity of the arc velocity during welding. In a short time when the metal is between the breakaway "island" and the base metal were in a molten or solid-liquid state, diffusion could enrich it with carbon from the side of the base metal and alloying elements from the side of the weld melt, which, apparently, determined its final structure as martensitic.
In the case of the welding-up, when filling a repair groove with MMA using the buttered layer technique, the overheat region (Figs. 10, 11) according to external morphological characteristics corresponds to a homogeneous enough, partially tempered microstructure similar to the base metal in the initial state (Fig. 12), and consists of bainite and martensite of tempering. The grain diameter amounts to $40 \ldots .55 \mu \mathrm{m}$ ( 6 points) and indicates a satisfactory degree of grain refinement compared with the critical case (see Fig. 5). A metallographic study of the overheat region and the fusion zone along its entire length did not reveal any defects.

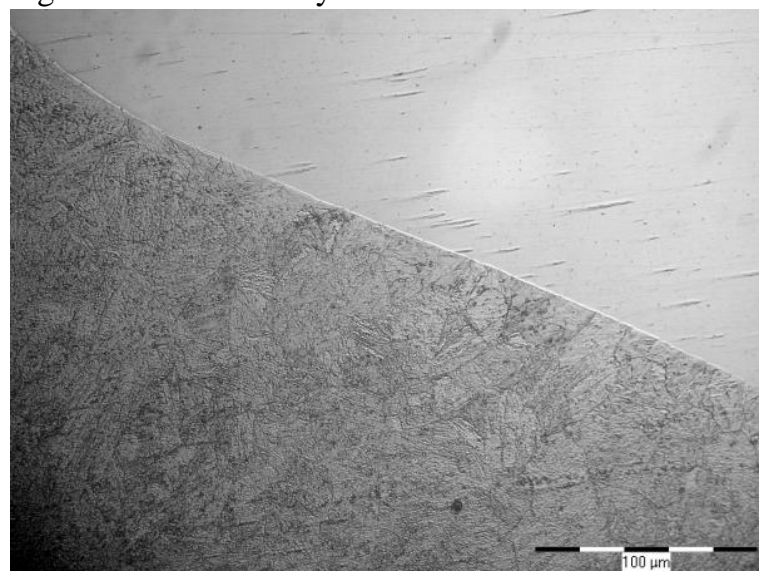

Fig. 10. The structure of the overheating area $(\times 400)$ when surfacing with MMA with buttered layer technique

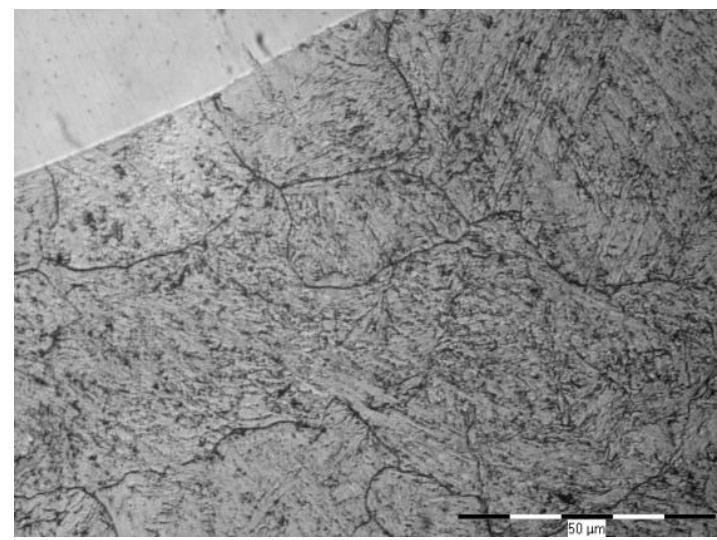

Fig. 11. HAZ structure $(\times 1000)$ in the vicinity of the fusion zone when surfacing with MMA using the buttered layer technique

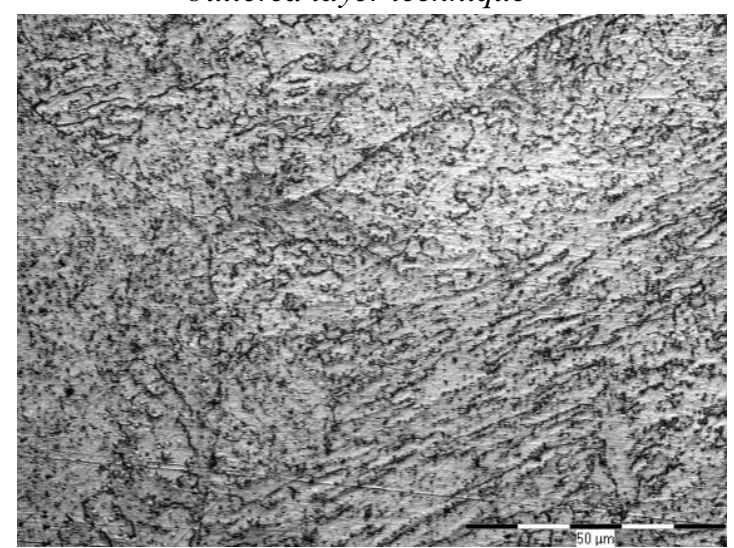

Fig. 12. The base metal in the initial state $(\times 1000)$ 
Based on the results of metallographic studies, it was found that in the aspect of overheating of the heataffected zone, MMA is a more appropriate welding process than TIG. This method with a layer-by-layer controlled change in linear energy provides the most uniform and fairly fine-grained metal structure in the overheat region of the HAZ in 15Kh2MFA steel.

To assess a ductility of the repair welded joint metal, another simulative repair welded joint was made of steel $15 \mathrm{Kh} 2 \mathrm{MFA}$. The machine-cut groove was performed without sharp corners in its cross-section, but otherwise it was similar in shape to that in Fig. 1. The dimensions of the plate and the length of the groove in this case (Fig. 13) allowed the production of the transverse face bend test specimens according to the type approved by 11.5 of the ПНАЭГ-7-002-86

The repair groove was welded up by MMA with the buttered layer technique under above conditions. Nondestructive quality control by ultrasonic testing revealed the absence of defects in the deposited metal and HAZ.

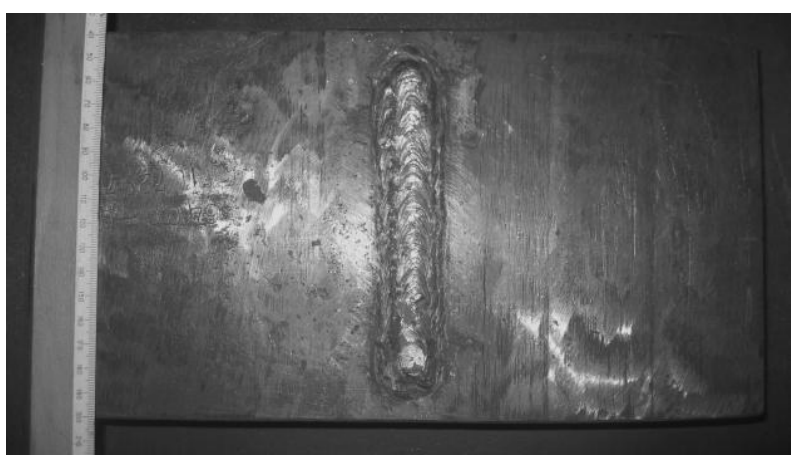

Fig. 13. Simulative repair welded joint of steel 15Kh2MFA

The transverse face bend test was carried out by loading the specimen until unacceptable damage appeared. The specimen dimensions was (in $\mathrm{mm}$ ): length 305; width 45; thickness 30 . The distance between the rollers 100 ; the diametr of the rollers 50 ; the diameter of the inner roller 60 . As the testing has shown, the smallest bending angle for the two tested specimens was 53 (Fig. 14). It is satisfactory result according to 11.10 of the ПНАЭГ-7-010-89.

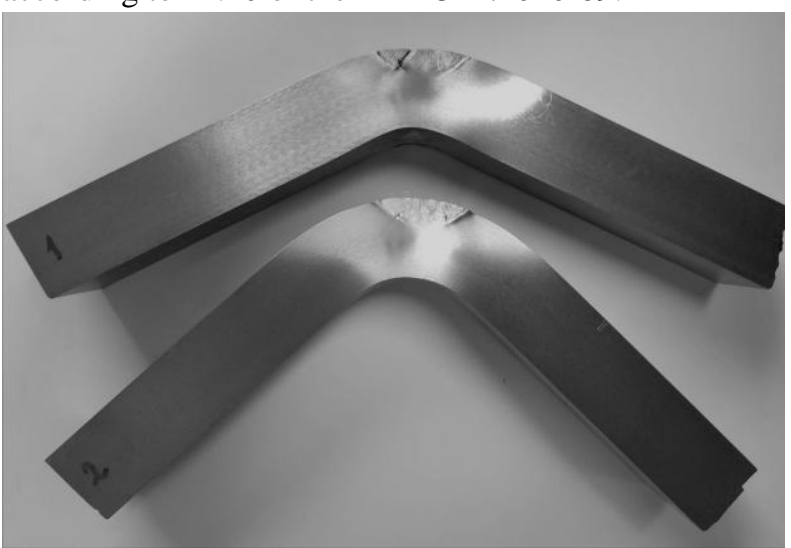

Fig. 14. View of transverse specimens after bend testing

The bending of both specimens led to the crack propagation in the deposited austenitic metal, caused by the exhaustion of its plastic properties due to the concentration of the plastic flow within the welded-up groove crosssection due to the perceptible difference in the yield strength of the weld metal and the base metal. No damage was detected in the fusion zone or along the HAZ.

A metallographic study was also carried out on two transverse thin sections cut from the welded joint in the middle area along the length of the groove. No crack-like defects in the HAZ metal and weld metal were detected.

\section{CONCLUSIONS}

1. The ordinary renewal of the reactor vessel anticorrosive coating by arc welding methods is applicable with the severe limitation on the depth of removable defects, otherwise it can lead to unfavorable structural changes in the metal of fusion zone and overheat region of the HAZ in 15Kh2MFA steel (grain growth, chemical and structural inhomogeneity), which lead to a decrease in the plastic properties of the metal in those areas.

2. In order to develop a technology for repair by austenitic welding materials of damage to the anticorrosive coating of the reactor vessel that goes into the base metal, without the subsequent high-temperature heat treatment, the known repair MMA welding technique with layer-by-layer controlled change in heat input was applied and a set of preliminary studies was carried out.

3. The results of carried out metallographic studies as part of development of a new repair welding technology for the reactor vessel anticorrosive coating, taking into account the arc access to the base metal, as well as the results of the transverse face bend test indicate the real possibility of ensuring the proper quality of the repair welded joint without hightemperature heat treatment.

4. For the 1st layer of surfacing when repairing damage to an anticorrosive coating that deepens into the base metal, it is advisable to choose coated electrodes of the 3ИО-8 grade, the deposited metal of which is not tended to the initiation of hot cracks.

5. In order to develop and implement the technology of recovery surfacing without subsequent heat treatment in relation to the WWER-440 reactor vessel, it is necessary to agree the results in the established order, work out a production certification program, carry out a set of certification tests and, if positive, confirm a statement on the adaptation of new weld repair method.

\section{REFERENCES}

1. Ю.Л. Коврижкин, В.И. Скалозубов, В.Ю. Кочнева. Научно-технические основы оптимизации планирования ремонтов, испытаний и контроля на $A Э C$ c BВЭР. Чернобыль: «Институт проблем безопасности АЭС», 2009, $120 \mathrm{c.}$

2. Правила и нормь в атомной энергетике. Оборудование $и$ трубопроводы атомных энергетических установок. Сварка и наплавка, основные положения. ПНАГЭ-7-009-89. М.: «Энергоатомиздат», 1991, $320 \mathrm{c}$.

3. В.Н. Земзин. Сварные соединения разнородных сталей. М.-Л.: «Машиностроение», 1966, 232 с.

4. В.А. Винокуров. Отпуск сварных конструкций для снижения напряжений. М.: «Машиностроение, 1973, 213 с. 
5. Г.Л. Петров, В.Н. Земзин, Ф.Г. Гонсеров-ский. Сварка жаропрочных нержавеющих сталей. М.-Л.: «Машгиз», 1963, 248 с.

6. Ю.Н. Готальский. Сварка перлитных сталей аустенитными материалами. Киев: «Наукова думка», 1992, 224 с.

7. Ю.Н. Готальский. Сварка разнородных сталей. Киев: «Техника», 1981, 184 с.

8. В.Ф. Грабин. Металловедение сварки плавлением. Киев: «Наукова думка», 1982, 416 с.

9. P.J. Alberry, J. Myers, and B. Chew. An improved welding technique for heat affected zone refinement // Welding and Metal Fab. 1977, N 11, p. 549-553.

10. K. Ikeuchi, J. Liao, H. Tanabe. Effect of temper bead termal cycle on toughness of weld ICCG HAZ of low alloy steel SQV-2A // ISIJ, International. 1995, v. 35, N 10, p. 1203-1212.

11. C. Delamarian. Manual for Maintenance and Retrofit of Conventional Power Plants. Timisoara: Editura Sadura, 1998, 256 p.

12. C.D. Lundin. Overview of Results from PVRC Programs on Half-Bead /Temper-Bead/ Controlled Deposition Techniques for Improvement of Fabrication and Service Perfomance of Cr-Mo Steels: Proceedings of the Workshop "Challenges and Solutions in Repair Welding for Power and Process Plants" // WRC Bulletin. 1996, v. 412, p. 16-26.
13. A. Sadek, H. Hussein, M. Ushio. Effect of repair welding technique on the mechanical properties of thick wall structural steel // Trans. JWRI. 2001, N 1, p. 53-61.

14. R. Mizuno, P. Brziak, M. Lomozik, F. Matsuda. Appropriate Welding Conditions of Temper Bead Weld Repair for SQV-2A Pressure Vessel Steel // 30-th MPASeminar in conjunction with the 9-th German-Japanese Seminar. Stuttgart, October 6 and 7, 2004, 7.1-7.9 p.

15. W.J. Sperko. Exploring Temper Bead Welding // Welding Journal. 2005, v. 84, N 7, p. 37-40.

16. Ф.А. Хромченко. Сварочные технологии при ремонтных работах. М.: «Интермет Инжиниринг», 2005, $368 \mathrm{c}$.

17. M. Higuchi, T. Umemoto, A. Matsusita, T. Shiraiwa. Development of Temper-Bead Technique Applied to Dissimilar Welded Joints of Nuclear Pressure Vessels: Proceedings of the Workshop "Challenges and Solutions in Repair Welding for Power and Process Plants" // WRC Bulletin. 1996, v. 412, p. 77-86.

18. В.Д. Ходаков, А.С. Зубченко. Опыт эксплуатации и ремонта разнородных сварных соединений оборудования и трубопроводов из аустенитных и перлитных сталей // Bonpocbl атомной науки и техники. Серия «Обеспечение безопасности АЭС». 2008, в. 23 «Реакторные установки с ВВЭР», с. 103-108.

\title{
РАЗРАБОТКА ТЕХНОЛОГИИ РЕМОНТА АНТИКОРРОЗИОННОГО ПОКРЫТИЯ ГЛАВНОГО РАЗЬЕМА КОРПУСА РЕАКТОРА ВВЭР-440
}

\section{С.И. Моравецкий, О.Г. Касаткин, А.К. Царюк, В.П. Кравец, И.В. Гончаров, А.В. Иванько}

Исследовалось влияние способа сварки на структуру металла зоны термического влияния (ЗТВ) в разнородном сварном соединении корпусная реакторная сталь + наплавленный аустенитный слой. Результаты металлографических исследований и испытаний на изгиб металла сварных соединений показали, что разработка технологии ремонтной наплавки антикоррозионного покрытия с выходом в основной металл корпуса реактора без последующего его высокого отпуска целесообразна на основе техники промежуточного слоя при сварке покрытыми электродами с послойным контролируемым изменением погонной энергии. Этот подход обеспечивает на участке перегрева однородную мелкозернистую структуру. Ручная аргонодуговая сварка с подачей присадки и послойно неизменной погонной энергией также позволяет измельчить зерно на участке перегрева. Однако при этом для него характерны два вида структурной неоднородности, связанные с интенсивным перегревом основного металла и диффузией легирующих элементов и углерода.

\section{РОЗРОБКА ТЕХНОЛОГІЇ РЕМОНТУ АНТИКОРОЗІЙНОГО ПОКРИТТЯ ГОЛОВНОГО РОЗ'ЄМУ КОРПУСУ РЕАКТОРА ВВЕР-440}

\author{
С.І. Моравецький, О.Г. Касаткін, А.К. Царюк, В.П. Кравець, І.В. Гончаров, А.В. Іванько
}

Досліджувався вплив способу зварювання на структуру металу зони термічного впливу (3ТВ) у різнорідному зварному з'єднанні типу корпусна реакторна сталь + наплавлений аустенітний шар. Результати металографічних досліджень та випробувань на згин металу зварних з'єднань показали, що розробка технології ремонтної наплавки антикорозійного покриття з виходом в основний метал корпусу реактора без наступного його високого відпуску доцільна на основі техніки проміжного шару при зварюванні покритими електродами з пошаровою контрольованою зміною погонної енергії. Цей підхід забезпечує на ділянці перегріву ЗТВ однорідну дрібнозернисту структуру. Ручне аргонодугове зварювання 3 подачею присадки і пошарово незмінною погонною енергією також дозволяє подрібнити зерно на ділянці перегріву. Однак при цьому для неї є характерним два види структурної неоднорідності, пов'язані з інтенсивним перегрівом основного металу і дифузією легуючих елементів та вуглецю. 